\title{
Saudi EFL Teachers' Readiness and Perceptions of Young Learners Teaching at Elementary Schools
}

\author{
Joza Fahd Al Malihi ${ }^{1}$ \\ ${ }^{1}$ King Saud University, Riyadh, Saudi Arabia \\ Correspondence: Joza Fahd Al malihi, King Saud University, Riyadh, Saudi Arabia. E-mail: \\ jozafahd@gmail.com
}

Received: November 5, 2014 Accepted: December 8, 2014 Online Published: January 20, 2015

doi:10.5539/elt.v8n2p86 URL: http://dx.doi.org/10.5539/elt.v8n2p86

\begin{abstract}
This study aimed to investigate EFL elementary school teachers' perception of their own readiness to teach young learners at Saudi schools as it has been recently introduced at this level. Further, it inspects their major needs that should be considered when developing teacher-training programs. A questionnaire was distributed targeting elementary EFL teachers. 114 responses from both male and female EFL elementary school teachers from different areas of the kingdom of Saudi Arabia mostly from the eastern province were collected. Data was analyzed and computed. The results revealed that most of the EFL teachers were not fully ready to teach at this level since more than half of them did not receive enough pre-service nor in-service training concerning young learners' teaching. Additionally, the teachers' responses showed high enthusiasm towards teaching elementary students and considered it as a necessity. The study also surveyed the teachers' perception of their own needs in terms of teacher training programs for these to be designed based on their personal point of views. Their priorities were mostly centered on using technology in young learners' classrooms, methods and teaching strategies that suits young learners, and choosing and designing materials and activities that are suitable for the developmental stages of children. The study came up with valuable insights to those who are concerned and involved in teacher training.
\end{abstract}

Keywords: elementary school, needs analysis, training program, professional development

\section{Introduction}

Teaching English to young learners in Elementary schools has become an important educational policy in Asian countries and many other countries around the world. Saudi Arabia has a great concern over teaching English to younger levels due to the growing power of the language around the world trying to cope with the new Educational policies."Education Policy in the Kingdom of Saudi Arabia discussed a program to introduce English language studies at primary schools in the Kingdom in order to expose its youths to the idea of acceptance and tolerance of others" (Elyas, 2008). Its high impact over globalization and its growing need as a necessity urges more research and investigation to keep up with the wheel of development on all life aspects. Including it as a compulsory subject at younger levels is unavoidable. It is only through such investigation drawbacks are detected and lacks are fulfilled. That is to follow up with the growing demand in providing teachers with the best up-to-date practices and methodology through well-designed teaching training programs producing teaching methods that can compete with the rest of the world. Through the results of such research, the correct starting points of new beginnings can be captured to pave the way for new brighter future.

It is well acknowledged in education, that teachers have a high impact on students' performance. They are the single most influential factor contributing to the teaching/learning process (Strong, 2000). Recent research has found that teachers produce a strong cumulative effect on students' achievement (Wright, Horn, \& Sanders, 1997). This study intends to highlight the level of present elementary school teachers' readiness to teach young learners and deal with this sensitive, fundamental age group through investigating their needs. Information on their pre-service education and in-service training programs are surveyed as well as their reflections on their own needs and attitudes concerning young learners' teaching.

\section{The Purpose of the Study}

The main objective for conducting this study is to investigate the Elementary English language present teachers' lacks and needs. Additionally, it attempts to suggest types of needed programs to be conducted by teacher training 
centres belonging to the Ministry of Education to prepare ahead for both existing teachers and teachers proposed to start with younger learners in the future plan for teaching earlier grades.

The Following are the research questions:

1) How far is Saudi EFL elementary school teachers prepared for teaching in elementary schools?

2) What are the present elementary school EFL teachers' attitudes towards EFL teaching at elementary levels in Saudi Arabia?

3) What are the suggested programs that fulfil the needs of present Elementary English language teachers in Saudi Arabia?

\section{Definition of Terms}

The following terms could be operationally defined as:

Elementary school: the primary level in Saudi schools extending from grade 1 at the age of six to grade 6 at twelve.

Needs analysis: Brown (1995) defines needs analysis as "the systematic collection and analysis of all training programs subjective and objective information necessary to define and validate defensible curriculum purposes that satisfy the language learning requirements of students within the context of particular institutions that influence the learning and teaching situation." The outcome of the needs analyses should set a list of objectives and goals that "serve as the basis for developing tests, materials, teaching activities, and evaluation strategies, as well as for reevaluating the precision accuracy of the original needs assessment" (Brown, 1995, p. 35).

Training program: A program designed for training in specific skills, which consists of a series of courses, and usually has a flexible time and cost budget.

Professional development: In education, it is a process of specialized training, formal education, or advanced professional learning intended to enable teachers, and other educators to improve their professional knowledge, competence, skill, and effectiveness.

\section{Background}

\subsection{EFL Teaching in Saudi Elementary Schools}

Recently, English language has found itself as a compulsory subject, in almost all primary schools in the whole world within different contexts. In Saudi Arabia, its presence at these levels has always been controversial and raised so much debate."The demand for English is always going to be there, stronger than ever with increasing globalization. After 9/11, the need to learn English in order to understand what is being said and written about Arabs is present more than ever. Arabs cannot stand still not knowing what the others are thinking and presuming about them" (Elyas, 2008). It was only included in the curriculum in Saudi Primary schools in KSA in 2003 (Elyas \& Picard, 2010). It was introduced gradually in Saudi Arabia's Elementary schools starting with sixth graders. Later in 2008, it was experimented in the fourth grades then the fifth, and the decision came up officially for these levels at 2011. Furthermore, it is intended for it in the coming few years to start with the earlier ages as well. Saudi children receive two-45-minute lessons per week. The main objectives of teaching English at this level are to:

- Learn the basics of the English language that would form the foundation for its mastery in the future.

- Use the basic structures of English sentences.

- Learn the core vocabulary assigned for this stage.

- $\quad$ Listen to and understand simple English language.

- $\quad$ Read and understand simple written English language materials.

- Write simple guided sentences in English language.

- Appreciate the importance of English language as an international language of communication, for introducing Islam, the Islamic nation's culture and the cultural achievements of Muslims to other nations.

- Appreciate the importance of English language as an international language of communication to benefit from the achievements of other cultures in accordance with Islam.

Much effort and experimenting are being put in the elementary school EFL teaching in an attempt to level up the unsatisfying English language teaching outcomes in Saudi Arabia.

\subsection{EFL Teaching to Young Learners}

For EFL teachers to be effective in their classes, they require basic competencies. The ten core dimensions of 
language teaching expertise and practice according to Richards (2011) are language proficiency, content knowledge, teaching skills, contextual knowledge, language teacher's identity, learner-focused teaching, pedagogical reasoning skills, theorizing from practice, membership of a community of practice and professionalism. Taking the contextual knowledge aside, it is the full awareness of the learning settings or context in which language learning is taking place. Whether teaching English is as second or foreign language, or teaching in a public school or private language institute, the learners may be children, teenagers or adults. Moreover, the social and cultural surroundings of the learning environment as a whole should be kept in consideration as well. When teachers find themselves in a surrounding where they are teaching children they must adapt all the previously mentioned competencies to fit this context. Therefore, they should be well aware of all their learners' age group and psychological background. Integrating theory into classroom practice is very important. Hence, teachers of young learners should be attentive to the crucial factors concerning the characteristics of the age group they are approaching. Such factors, for example, include as Cameron (2003) suggests that unlike adults, young learners cannot analyze language in an abstract way. They cannot compare language patterns with their mother tongue nor use their knowledge of the world and different contexts to guess meanings of new words for example. Rather:

- They use their limited and partial knowledge of the world to make sense of what is said to them and what is expected from them to do. They actively try to construct meaning through what goes around them, which should be taken in consideration when selecting classroom activities.

- Young learners intentionally see the foreign language from inside trying to find meaning in how the language is used in action and interaction rather than from the outside as a system or form.

- Language in use carries out cues to meaning that may not be noticed. Therefore, they need skilled assistance to realize aspects of the language that carry meaning. Scaffolding plays an essential role. Teachers aid learners in their tasks until language becomes internalized.

- They do not repeat what they hear, rather they try to come up with their own rules to figure out meaning and employ it for themselves (Wells, 1999).

- They are such active learners, processing new experiences, asking questions, trying things out, experimenting, practicing repeatedly until they master new skills (Donaldson, 1978; Tizard \& Hughes, 1984; Montessori, 1983).

Acknowledging and integrating theory in young children's teaching should be one of the basic qualities of the teachers of the elementary level.

\subsection{EFL Teachers in Saudi Arabia}

Teaching English to young learners is new to existing teachers as most of them have more experience with teaching secondary and intermediate levels. Moreover, EFL teacher preparation programs in the Kingdom of Saudi Arabia can be described as non-systematic and inadequate. Zaid (1993) said that EFL teachers over the last four decades have mainly been graduates of colleges of education and faculties of arts associated with Saudi universities offering bachelor's and associate's degrees in English language and literature. Colleges of education emphasize the educational aspects in the preparation of their students. Colleges of arts prepare students to be English or English-Arabic translation specialists — not necessarily English teachers.Like novice teachers in other faculties, they take, in Arabic, courses such as educational psychology, evaluation, school administration, and curriculum studies. None of these courses meets the needs of would-be EFL teachers (Al-Hazmi, 2003). Al-Seghayer (2011) pointed out those English teaching-methods courses only represent $10 \%$ of the total courses offered in colleges and universities by English departments. He stated "...the current programs are inadequate with regard to disciplinary knowledge, pedagogical content knowledge, and technological pedagogical knowledge" (Al-Seghayer, 2011, p. 22).

\subsection{In-Service Teacher Training for Professional Development}

Good teachers produce good students (Rice, 2003), but teachers do not enter the classroom as professionals. Most teachers develop, improve themselves and grow overtime. Moreover, training programs are essential in providing teachers with professional skills to keep them up-to-date concerning teaching methodology. When designing teacher-training programs, questions such as "Why is the program designed?" and"What are the expected outcomes?"Answers to these questions help in pointing out the aims and setting the objectives that should be achieved at the end of the program. These aims are mostly set based on the nature of the program. Whether it was introducing teachers to new ways out of developing and innovation that represent the institution's needs or providing them with skills they lack or want, both ways lead to an important feature in teacher training, and that is the needs analysis. 
The needs of the targeted teachers can be searched and analyzed through, for example, surveys, interviews and documentation. These needs can be classified as lacks and wants. The lacks can be skills that an EFL teacher does not have and should obtain such as correct pronunciation, classroom management, planning and lesson preparation, and these are usually decided through teachers' evaluation. The wants are usually skills that teachers like to obtain and seek in order to develop themselves professionally such as new teaching strategies or electronic teaching for instance. By making a clever balance between lacks and needs, designers can come up with a program that develops what teachers lack through what teachers want to learn.

\section{The Review of the Literature}

It is well acknowledged both theoretically and practically that teachers are among the principle components of any educational program influencing students' achievements. Sanders (1998) stated, "Single largest factor affecting academic growth of population of students is differences in effectiveness of individual classroom teacher." Furthermore, Alexander and Fuller (2005) argued, "few educators, economists or politicians would argue with the contention that all things begin equal, highly qualified teachers produce greater student achievement than comparatively less qualified teachers." This chapter presents some of the literature concerned with teacher training and teachers' professional development based on teachers' needs to bring valuable insights for the present study.

\subsection{EFL Teachers and Professional Development}

There is an increasing worldwide demand for competent, well-prepared English language teachers and more effective approaches towards their professional development. In Medellin, Colombia Gonzalez, Montoya and Sierra, (2002) reported in their study the needs EFL teachers seek in their professional work. They suggested that teachers experience needs in three different domains of their professional lives: as workers, as instructors and as learners pointing out that the importance of their roles as workers and learners have been denied compared to their role as instructors in previous traditional approaches. They argued that teacher educators and teacher education programs need to become aware of the teachers needs as learners and provide them with opportunities to develop their autonomy in learning as an additional component to their keeping abreast with new teaching techniques required. They also emphasized that Schools administrators' should acknowledge teachers efforts and motivate them to pursue self-development and growth when being involved in professional development programs. They also pointed out the positive effect of crediting training through financial rewarding and recognition of teachers' roles as contributors to the development of their own institution. Obtaining this can be through promoting the use of group development based on the teachers' experiences in training programs presenting an opportunity to motivate other colleagues creating communities of teachers sharing concerns and interests to engage in growth as a group.

Chou (2008) conducted a case study on three in-service teachers through interviews and classroom observation, teachers' reflective journals and teaching materials. The study came up with the conclusion that in order to make elementary English instruction successful in an EFL context, it is necessary to set up a sound in-service teacher training program for English teachers. Helping them to get equipped as competent English teachers, acquire more English knowledge and pursue professional development. He also emphasized the importance of the collaboration between practitioners, researchers and teacher educators. As it guides teachers to understand their own professional development, offers opportunities for researchers and teacher educators to investigate how teachers put theory into practice in L2 education and see how educational policies are working.

\subsection{EFL Teachers' Efficacy and Attitude Influence on Learners' Performance}

An important aspect affecting teachers' professional development is their attitudes towards teaching the elementary level in which teachers' motivation plays an essential role. Alshumaimeri (2011) reviled impressive results concerning teachers' attitudes in a study that targeted 327 male and female teachers. His study also covered other aspects regarding EFL at elementary levels in Saudi Arabia that are the learning settings and teaching materials, teachers' perceived skills and language competence, parents' cooperation with the school, and the role of ministry supervisors. Additionally, according to the findings, the teachers positively perceived their teaching skills, and they were confident of their language competences.

In a descriptive qualitative case study presented by Aydin (2012) in Turkey on a 26-years old EFL elementary school teacher, he concluded that six main factors cause demotivation during the EFL teaching process. They included problems relating to the teaching profession, curriculum, working conditions, students and their parents, colleagues and school administration, and physical conditions. He stated that demotivation could be a barrier for a continuing, improving, interesting and enjoyable teaching and learning. He recommended that teacher-training programs developed require revision in terms of methodology employed in the course, computer assisted/based EFL teaching and learning, and good preparation for special education for children. 
Akbari and Allvar (2010) investigated three teacher-related variables, which are teaching style, teachers' sense of efficacy and teacher reflectivity to see how they relate to student achievement gains in an English-language teaching context. Their study involved thirty EFL teachers teaching in the Iranian junior and senior high schools. The participating students' final-exam scores as an independent variable showed that the study variables could predict student achievements. The results of the study revealed a high correlation between teacher reflectivity and student achievement outcomes. Reflective teachers are more interested in growing and learning; they are always in search for new ideas and techniques. Their reflective practice generates from passion to help children succeed. "The results of the study imply that teacher education programs should familiarize, perceive and even in-service teachers with the components of reflective teaching if they want to educate effective teachers." Moreover, the results of the study indicated a positive relationship between a teacher's sense of efficacy and student achievement. Teachers who possess a secure sense of efficacy show a strong commitment to teaching and devote more overall time to the subject matter and academic matters. Their self-efficacy affects their instruction choices, level of effort and persistence with students. Efficacious teachers use effective management strategies that stimulate student autonomy, reduce custodial control and keep students on tasks. Out of their confidence in their teaching abilities, they are more willing to cooperate with parents and try to let keep them aware of their educational performance.

Examining the efficacy beliefs of nonnative English speaking Iranian EFL teachers, Eslami and Fatahi (2008) using the Teacher Sense of Efficacy Scale found that novice Iranian EFL teachers feel more efficacious in applying instructional strategies than in managing classes. They motivate and engage students more than implementing instructional strategies. In their study, they argue that there is a positive relationship between perceived level of language proficiency and sense of self- efficacy. The higher the teacher' perceived proficiency in language skills, the more efficacious they felt, thereby, developing more tendency to use communicative-based strategies in their classes and inclination to focus more on the meaning rather than accuracy leading to better learning environment.

Correlation between perceived efficacy and self-reported English proficiency was also the result indicated by Chaco'n (2005). The study was conducted in Venezuela. It surveyed 100 teachers and showed that teachers' efficacy for instructional strategies was higher than efficacy for management and engagement. It concluded that EFL teachers require adequate preparation not only in grammar, reading and writing but also in speaking and listening so that they build a strong sense of efficacy to use language not only to motivate and engage students, but also to design instructional strategies.

\subsection{Needs Analysis and Teacher Training Programs}

Aiming to develop EFL English teachers performance at Sana'a secondary schools, in his Ph.D. thesis Zuheer (2013), proposed a list of what he described as the most necessary four needs for English teachers. They were effective communications skills, reflections, integrating language skills and intercultural competence. His study consisted of (25) English teachers who voluntarily participated in a seven-week training program developed by the searcher based on the four professional and specialist needs to develop their teaching performance. He used a pre-post achievement test to assess the knowledge aspects of the EFL teachers besides the observation checklist applied by the searcher himself. The results of the study revealed that the participants achieved the main aim of the study program as their teaching performance level was improved due to the program of the study. He stated that this positive result is reached because teachers play an active role in their own professional development, meaningful knowledge and learning was accomplished through collaboration and reflection around personal experiences. Moreover, knowledge about language teaching and learning is in a tentative and incomplete state, and teachers need regular opportunities to update their professional needs. According to him, the teachers had opportunities to improve performance through arranged interaction by processing aspects of their teaching using multiple activities, exchanging experiences and having a chance to change teaching settings.

Alwan (2000) in the UAE examined the effectiveness of the current in-service teacher training (INSET) provision and the possibility of introducing self-directed (school-based) teacher development activities to teachers of English as a foreign language. The findings revealed that the (INSET) in UAE does not follow a defined system and teachers are not directly consulted when defining training needs. There is no follow up system to examine the effectiveness of the training courses provided. Moreover, teachers practice self-directed development activities on a limited scale. Many of them as she described are "report-driven" as they practice certain activities to gain the approval of their supervisors and principals who are in charge of their final appraisal reports. Self-development activities like journal writing and self-appraisal are rarely practiced. She found out that some teachers do not know that such methods exist.

Igawa (2008) stated that as professionals, teachers should continually improve themselves. Their own growth is necessary in order to cope with the ever-expending knowledge base in subject matter and pedagogy, rapidly 
changing social contexts of schooling, and increasingly diversifying students' needs. He surveyed the needs of 44 in service secondary and higher education teachers of English teaching in Japan and Korea, attending an annual three-day professional development seminar that was held in Osaka, Japan. The most agreed upon need among the participants was the "Teaching Skills and Methods"; the "language improvement" came second and in both the third and fourth place came "Communication Skills" and "Motivation". He also pointed out there was a difference in the participants responses concerning the "Teaching Skills \& Methods" attributed to both contexts of English language education in both countries and their policies. Further, he included in his findings that the professional development of this particular need gradually decline as the teachers' years' in-service increase. Young teachers are more interested in communication skills to promote students' motivation than experienced ones.

\subsection{EFL Teachers' Needs Analysis at Elementary Levels}

In his study, Wati (2011) examined the effectiveness of the English teacher training program of elementary school English teachers and their further needs in Riau Province, Indonesia. The sample included fifty-five English teachers who attended a training program that proved to be highly effective in terms of overall effectiveness and in improving teachers' confidence and motivation. But it was not in terms of improving the Basic English knowledge as the most important aspect for being effective EFL teachers. He concluded that the majority of teachers stated they needed basic English knowledge to be given in next training program since the findings also revealed they lack both language and pedagogical competence, English teachers were neither communicatively competent as language teachers. He said that additional language-training programs for English teachers are needed to be designed according to the essential aspects that are desired by the English teachers in teaching English.

Kusumoto (2008) conducted a needs analysis for Japanese elementary school homeroom teachers that aimed at developing a teacher training program. The findings of the study that were surveyed through a Questionnaire answered by 256 teachers, illustrated the complex and undeveloped context of teacher training in Japan. In the sametime, it provided valuable implications for curriculum developers and teachers in developing teacher-training program based on their own needs and language proficiency was again an essential need for most teachers.

Unlike the research presented, teachers' language proficiency in Saudi elementary schools should not be in question since all elementary school teachers are English language department graduates whether educational or of other faculties. Leading them not only to be good speakers of the language but also sometimes specialists in it as in the case of linguistics, literature and translation faculties' graduates. However, it has been widely argued that EFL Saudi teachers are neither competent in English nor in teaching it. A recent study by Javid, Farooq and Gulzar (2012) examined Saudi English-major undergraduates and English teachers in Taif University. It concluded that one of the main causes of ineffective ELT in Saudi universities is the lack of the required English proficiency among the students who apply in the English departments of Saudi universities resulted from the Saudi EFL School teaching standards that should be investigated. The fact that present students are future teachers keeps an ongoing circle emphasizing the point of the importance of professional EFL teacher training. However not excluding the fact that English language teachers in Saudi Arabia have language proficiency on different levels at least in a way that is appropriate for elementary level teaching.

All the reviewed studies insisted on professional development and more teacher training programs for improved educational environments and better teaching outcomes. Moreover, teachers' attitudes and working environment are also given considerable attention since they affect their motivation towards professional development. In return, to develop and create beneficial and successful teacher training programs, these teachers' basic and real needs must be examined. Therefore, a needs analysis as the one conducted in the present study must be piloted before designing any training programs to save time, money and energy wasted on unplanned, useless and random training. Based on such needs analysis, those who are in charge of designing teacher-training programs can set their first steps in the right direction towards teachers' professional development.

The study in hand comes to support and in line with most of the reviewed literature giving more emphasis to the specialty of the requirements needed to teach young learners other than linguistic proficiency. Moreover, a little investigation regarding the elementary school EFL teaching is available as it is recently introduced. Therefor this study comes to enrich researching materials concerning this field of Knowledge.

\section{Methodology and Data Collection}

It is a descriptive quantitative research surveying English language teachers' at elementary level needs and lacks through collecting their response to the Questionnaire that was developed for this purpose.

\subsection{Instrument}

The questionnaire that was designed by the researcher consists of three main sections. The first was Teacher's 
background, investigating the teachers' graduation qualification, years of experience, pre- service and in-service training, and personal awareness of young learners teaching pedagogy and policies in and out of Saudi Arabia. The second tries to figure out the teachers' attitudes towards English language teaching in elementary levels and its requirements and how far they are willing to change their teaching ways to fulfill these requirements. The last part questions the teachers' priorities in choosing training programs based on what they think they need.

At the end of the questionnaire, two open optional questions were provided seeking the respondents' views on particular programs of their interests that were not mentioned and their personal remarks over teaching English to elementary levels based on their experiences.

Using Statistical Package forthe Social Sciencesprogram (Cronbach's Alpha); the instruments' reliability was computed and proved reliable at $(0.76)$ as shown in table 1.

Table 1. Reliability statistics

\begin{tabular}{ll}
\hline Cronbach's Alpha & N of Items \\
\hline .761 & 20 \\
\hline
\end{tabular}

The Questionnaire was first applied randomly on an exploratory sample of 16 EFL elementary school teachers in Qatif city to check its validity, objectivity and clarity before moving to the second step in generalizing it.

\subsection{Participants}

The targeted sample was elementary school English language teachers in Saudi schools both male and female graduating from both educational and Arts faculties.After distributing the questionnaire, 114 responses from different cities of the kingdom of Saudi Arabia mostly from the eastern province were collected and analyzed. Students at elementary levels took two periods per week at the sixth grade. As for the fourth and fifth graders, it is recently experienced, and not all schools apply it. Due to the low number of periods, most teachers teach into two schools, which also resulted in decreasing the possibility of reaching more participants.

\subsection{Procedure}

The questionnaire was distributed with the support of the Ministry of education in different elementary schools after obtaining all the required approvals. Data was collected both manually and electronically. All data was analyzed and computed through Statistical Package for the Social Sciences program. Many of the respondents left the optional open-ended questions not answered. For the First question, "Do you have any remarks or comments on Saudi English elementary education based on your previous experiences?" The researcher received 30 responses out of the total 114 respondents. As for the second, "Would you like to suggest any other subjects you would like to learn if you have teacher training?" 15 responses were received, and both open-ended questions were analyzed.

\section{The Results and Data Analysis}

\subsection{The Results}

Descriptive statistics were used and computed. Open responses were also gathered and analysed. The following tables summarise the percentage of responses to each section of the questionnaire.

A) Teacher's background

Table 2. Teachers' responses to the first section of the questionnaire

\begin{tabular}{|c|c|c|c|c|c|}
\hline No & Items & \multicolumn{4}{|c|}{ Percentage } \\
\hline \multirow{2}{*}{1} & \multirow{2}{*}{ I am a graduate of } & Arts colle & faculty & \multirow{2}{*}{\multicolumn{2}{|c|}{$\begin{array}{l}\text { Educational faculty } \\
57.89 \%\end{array}$}} \\
\hline & & $42.11 \%$ & & & \\
\hline \multirow{2}{*}{2} & \multirow{2}{*}{ I have an experience of } & $1-3$ years & 4-6 years & $7-9$ years & $10+$ \\
\hline & & $27.19 \%$ & $15.79 \%$ & $14.91 \%$ & $42.11 \%$ \\
\hline \multirow{2}{*}{3} & \multirow{2}{*}{ Did you have any pre-service training? } & Yes & & No & \\
\hline & & $44.74 \%$ & & $55.26 \%$ & \\
\hline
\end{tabular}




\begin{tabular}{|c|c|c|c|c|c|}
\hline 4 & $\begin{array}{l}\text { How many in-service EFL training programs } \\
\text { have you attended? }\end{array}$ & $\begin{array}{l}1-3 \text { prog. } \\
69.30 \%\end{array}$ & $\begin{array}{l}4-6 \text { prog. } \\
14.91 \%\end{array}$ & $\begin{array}{l}7-9 \text { prog. } \\
10.53 \%\end{array}$ & $\begin{array}{l}10+\text { prog. } \\
5.26 \%\end{array}$ \\
\hline 5 & $\begin{array}{l}\text { Which other levels you had previous experience } \\
\text { in teaching? }\end{array}$ & $\begin{array}{l}\text { None } \\
16.67 \%\end{array}$ & $\begin{array}{l}\text { Secondary } \\
9.65 \%\end{array}$ & $\begin{array}{l}\text { Intermediate } \\
22.81 \%\end{array}$ & $\begin{array}{l}\text { Both } \\
50.88 \%\end{array}$ \\
\hline 6 & $\begin{array}{l}\text { Have you had any training program concerning } \\
\text { young learners teaching theory and pedagogy? }\end{array}$ & $\begin{array}{l}\text { Yes } \\
41.23 \%\end{array}$ & & $\begin{array}{l}\text { No } \\
58.77 \%\end{array}$ & \\
\hline 7 & $\begin{array}{l}\text { Are you fully aware of the EFL young learners } \\
\text { teaching policy in Saudi Arabia? }\end{array}$ & $\begin{array}{l}\text { Yes } \\
48.25 \%\end{array}$ & & $\begin{array}{l}\text { No } \\
51.75 \%\end{array}$ & \\
\hline 8 & $\begin{array}{l}\text { Did you read about young learners EFL teaching } \\
\text { policies in other countries? }\end{array}$ & $\begin{array}{l}\text { Yes } \\
18.42 \%\end{array}$ & & $\begin{array}{l}\text { No } \\
81.58 \%\end{array}$ & \\
\hline
\end{tabular}

Note. Prog $=$ program

B) Teacher's attitudes

Table 3. Teachers' responses to the second section of the questionnaire

\begin{tabular}{|c|c|c|c|c|c|c|}
\hline No & Item & $\begin{array}{l}\text { Strongly } \\
\text { agree }\end{array}$ & Agree & Natural & Disagree & $\begin{array}{l}\text { Strongly } \\
\text { disagree }\end{array}$ \\
\hline 1 & $\begin{array}{l}\text { I think that teaching English to younger learners is a } \\
\text { must to cope with globalization and the growing use of } \\
\text { the English language in most present aspects of life. }\end{array}$ & 51.7 & $37.72 \%$ & $9.65 \%$ & $0.88 \%$ & $0.00 \%$ \\
\hline 2 & $\begin{array}{l}\text { I think that teaching English to young learners requires } \\
\text { special qualifications other than teaching intermediate } \\
\text { and secondary levels }\end{array}$ & $56.14 \%$ & $34.21 \%$ & $5.26 \%$ & $2.63 \%$ & $1.75 \%$ \\
\hline 3 & $\begin{array}{l}\text { I am willing to change my ways of teaching to fit the } \\
\text { new context when teaching younger learners }\end{array}$ & $51.75 \%$ & $35.09 \%$ & $10.53 \%$ & $1.75 \%$ & $0.88 \%$ \\
\hline
\end{tabular}

C) To teach English to young learners you need training programs on:

Table 4. Teachers' responses to the third section of the questionnaire

\begin{tabular}{|c|c|c|c|c|c|c|}
\hline No & Item & $\begin{array}{l}\text { Strongly } \\
\text { agree }\end{array}$ & Agree & Natural & Disagree & $\begin{array}{l}\text { Strongly } \\
\text { disagree }\end{array}$ \\
\hline 1 & $\begin{array}{l}\text { The English education teaching policy at elementary } \\
\text { schools in KSA. }\end{array}$ & $28.95 \%$ & $38.60 \%$ & $25.44 \%$ & $5.26 \%$ & $1.75 \%$ \\
\hline 2 & Introduction to second language acquisition theory. & $27.19 \%$ & $43.86 \%$ & $21.05 \%$ & $5.26 \%$ & $2.63 \%$ \\
\hline 3 & Young learners' Educational psychology. & $38.60 \%$ & $44.74 \%$ & $12.28 \%$ & $3.51 \%$ & $0.88 \%$ \\
\hline 4 & Using technology in young learners' classrooms. & $71.05 \%$ & $17.54 \%$ & $6.14 \%$ & $2.63 \%$ & $2.63 \%$ \\
\hline 5 & $\begin{array}{l}\text { Methods and teaching strategies that suit young } \\
\text { learners. }\end{array}$ & $57.02 \%$ & $34.21 \%$ & $6.14 \%$ & $1.75 \%$ & $0.88 \%$ \\
\hline 6 & $\begin{array}{l}\text { Choosing and designing materials and activities that } \\
\text { are suitable for the developmental stages of children. }\end{array}$ & $57.02 \%$ & $32.46 \%$ & $7.02 \%$ & $1.75 \%$ & $1.75 \%$ \\
\hline 7 & Young learners' classroom management & $47.37 \%$ & $41.23 \%$ & $9.65 \%$ & $1.75 \%$ & $0.00 \%$ \\
\hline 8 & Lesson planning. & $37.72 \%$ & $36.84 \%$ & $15.79 \%$ & $7.02 \%$ & $2.63 \%$ \\
\hline 9 & $\begin{array}{l}\text { Young learners' language development evaluation and } \\
\text { assessment. }\end{array}$ & $49.12 \%$ & $41.23 \%$ & $5.26 \%$ & $1.75 \%$ & $2.63 \%$ \\
\hline
\end{tabular}




\subsection{The Analysis of the Results}

\section{A) Teacher's background}

The results show that $57.89 \%$ of respondents were graduates of educational faculties. $55.26 \%$ of them did not have any pre-service training and $42.11 \%$ of them have experience of more than ten years.

Comparing the aspect of the pre-service training with the faculty of graduation did not show any advantage for educational department graduates over their peers of the Arts graduates as both type respondents showed almost similar responses. However, it shows that $55.68 \%$ of both parties did not have any pre-service training.

As for the training programs concerning young learners teaching theory and pedagogy, $58.77 \%$ of the respondents negatively responded. Even the $59.09 \%$ of the educational faculty graduates did not receive any training concerning young learners teaching theory and pedagogy that confirms what is proposed by (Al-Seghayer, 2011; Zaid, 1993; Al-Hazmi, 2003) that EFL teachers college education preparation is ineffective.

Regarding the number of in-service training programs, the findings showed that $69.30 \%$ of the respondents had only $1-3$ in-service training programs during their working experience. $45.83 \%$ of them have experience of more than 10 years, which reflects the scarcity of in-service training. $25.00 \%$ of the more than ten years experienced had 4-6 programs, and $18.75 \%$ had $7-9$ while only $10.42 \%$ had more than 10 .

Moreover, $51.75 \%$ of the respondents answered that they are not fully aware of the EFL young learners teaching policy in Saudi Arabia, expressing a lack of clearing the visions of new teachers about teaching policy. Only $18.42 \%$ of teachers showed curiosity in exploring young learners' EFL teaching policies in other countries. Indicating the importance of rising learning autonomy awareness of these teachers to take charge and responsibility of their own learning and development in the absences of adequate training.

It is concluded then, that more than half of the Elementary EFL teachers graduating from both types of faculties are not prepared with adequate pre-service preparationneither neither on educational level nor through adequate pre-service training programs. Moreover, they are not supported by enough in-service training programs to develop them professionally, and to update them with sufficient training to meet the new context of elementary level and young learners' teaching.

B) Teacher's attitudes

$89.47 \%$ of the teachers' responses showed both high and positive attitudes towards the importance of teaching English to Elementary levels.90.35\% reflected high awareness of the fact that there are special requirements needed for the young learners and $86.84 \%$ showed willingness to change their ways and methods to fit the new context. Reflecting high responsibility from their behalf once included in the decision making process in planning needed programs leading eventually to their own professional development and the success of such programs.

C) To teach English to young learners you need training programs on:

Though teachers expressed having prior training, the percentage of their priorities proves even more that this training was poor through their high demand for the proposed programs in the questionnaire. $71.05 \%$ of the teachers strongly need programs on using technology in young learners' classrooms. As it is clear that the language of technology is the language familiar to new generations, teachers need to equip themselves with it. In second place of demand came two important and essentials for teachers. They are methods and teaching strategies that suits young learners and choosing and designing materials and activities that are suitable for the developmental stages of children with the same percentage, and that is $57.02 \%$ of the teachers. Young learners' language development evaluation and assessment was strongly demanded by $49.12 \%$ of the respondents. Young learners' classroom management came up with $47.37 \%$. 38.60\% strongly wanted to learn about young learners' Educational psychology and $37.72 \%$ about Lesson planning. $28.95 \%$ of the teachers showed their strong need to know about the English education teaching policy at elementary schools in KSA, and $27.19 \%$ are interested in having an introduction to second language acquisition theory.

The priorities are arranged above based on the strongly agreed on needs, but this does not exclude the fact that once the percentages between the strongly agreed and agreed on programs are gathered as required needs, this may change their order to be as listed in table 5 . 
Table 5. The prioritiesarranged as required needs based on joining the percentages of both the strongly agreed and agreed on programs

\begin{tabular}{lllll}
\hline \multirow{2}{*}{ No } & Item & $\begin{array}{l}\text { Strongly } \\
\text { agree }\end{array}$ & Agree & Total \\
\hline 1 & Methods and teaching strategies that suit young learners. & $57.02 \%$ & $34.21 \%$ & $91.23 \%$ \\
2 & Young learners' language development evaluation and assessment. & $49.12 \%$ & $41.23 \%$ & $90.35 \%$ \\
3 & $\begin{array}{l}\text { Choosing and designing materials and activities that are suitable for the } \\
\text { developmental stages of children. }\end{array}$ & $57.02 \%$ & $32.46 \%$ & $89.48 \%$ \\
4 & Young learners' classroom management & $47.37 \%$ & $41.23 \%$ & $88.6 \%$ \\
5 & Using technology in young learners' classrooms. & $71.05 \%$ & $17.54 \%$ & $88.59 \%$ \\
6 & Young learners' Educational psychology. & $38.60 \%$ & $44.74 \%$ & $83.34 \%$ \\
7 & Lesson planning. & $37.72 \%$ & $36.84 \%$ & $74.56 \%$ \\
8 & Introduction to second language acquisition theory. & $27.19 \%$ & $43.86 \%$ & $71.05 \%$ \\
9 & The English education teaching policy at elementary schools in KSA. & $28.95 \%$ & $38.60 \%$ & $67.55 \%$ \\
\hline
\end{tabular}

Any of the ways this valuable information should pave the way for teacher trainers to design programs and urge training centres belonging to the ministry of education to start implementing them. That is to satisfy these teachers' needs and help them develop professionally and update them to be ready to teach young learners at elementary levels.

D) The open questions:

From the question, do you have any remarks or comments on Saudi English elementary education based on your previous experiences? The teachers provided valuable insights to be taken into consideration. Their views varied between suggestions, criticism and demands. The most strongly recommended idea by most responses was that English language teaching should start earlier and cover all elementary levels for language teaching to give better outcomes. Here are six of their views:

Participant \#12 "Saudi English elementary starting late. It should start in the start in first elementary school."

Participant \#108 "They must teach English from the kindergarten stage because children have to use to it.And after they finish secondary stage they will go through English test for job requirement"

Participant \#99 "Teaching Eng. alphabet in the third grade to let children know them very well songs also can be helpful"

Participant \#95 "I hope to teach English from grade 3"

Participant \#83 "Yes. For young learners elementary they need to apply at all levels school"

Participant \#75 "Yes. For young learners' elementary they need to teach English L at all levels of school"

The number of periods was also strongly presented by another six of the 30 respondents who demanded more periods as they are not enough for both teaching and evaluation.

Participant \#7 “As English needs much practice, I think two periods a week are not enough for teaching children.”

Participant \#107 "Yes, two lessons per week in each class is not enough we need 5 lessons per week without increasing the lessons in the book."

Participant \#105 "I ask to extend the number of the period for teaching and evaluation"

Participant \#113"It needs to raise periods during the week"

Participant \#80 "English class should be everyday not only twice per week."

participant \#6 "2 English classes per week for young children is not enough, it should be at least 4 times a week English teachers in Elementary schools still suffer a lot from teaching other Arabic subjects to fill their schedule. The syllabus for this age particularly must be more flexible and depends more on playing. We are trying to fix this by merging games in classes but this not enough. -Students start at the beginning of the year with huge excitement, however, when the real courses start their interaction to acquire the language decrease remarkably. Even if we tried to change the learning styles. This proves the improperly of the syllabus to their age." 
As in the last response, there were also comments on the syllabus given to elementary levels.

Participant \#33 "I think that our courses are not good and enough to help kids gather language"

Participant \#22 "In fourth and fifth grade some lessons are difficult to learn according to their ages"

Participant \#9 "I think they need more interesting lessons games and songs and I think they have to make a small project at the end of each unit."

In addition, there were demands from teachers who suffer because of assigning teaching other Arabic subjects not of their specialty due to their low number of periods. Others suffer from being distributed between two schools for the same reason.

Participant \#87 "There is no planning for being a specialist teacher in each school. Most of teachers delegate into 2 schools .every year"

Participant \#41 "English teachers should only teach English and focus their energy on their subject instead of being given other subjects not related to their course like teaching religious subjects as an example"

There were also many complaints on the levels of schools' environment:

Participant \#104 "Elementary school teachers need fully equipped labs to address all the skills required in each grade."

Participant \#114 "Saudi schools need a special environment that suits teaching English such as English language classrooms"

Participant \#70 "I think we need fully equipped labs for English teachers in elementary grades it helps a lot and gives a different setting for the class"

Participant \#66 "The lack of motivating environment for ESL and lack of language laboratories"

Participant \#52 “I'm just aware of English education here since we don't have enough facilities to make improvement in English education"

There was one comment concerning teachers' related factors was "Most teachers are not trained at all" another one concerning learners' was "Students here are not cooperative unless five of twenty in the class. They think it is not necessary to learn a new language."

As for the second open question, would you like to suggest any other subjects you would like to learn if you have teacher training? The respondents provided a list of what types of programs to be designed. For example:

Participant \#113 "Dealing with problems"

Participant \#84 "Gifted students and special needs students programs"

Some of their suggestions include issues related to young learners' classroom management, methodology, second language acquisition theory and young learners' Educational psychology. So as:

Participant \#12 "We need to learn more about how to motivate students and their families for learning and studying English"

Participant \#6 "Yes, that is how to deal with daydreaming pupils and the children who do not like to talk even though they are healthy and not special needs and other problems"

Participant \#66 "Activating group work managing classrooms of large numbers of kids"

Participant \#87 "Behavioral objectives"

Participant \#52 "How to teach children writing How to teach vocabulary Ways of grouping students learning through play"

What really need so much attention are the following responses:

Participant \#65 “Just English”

Participant \#53 "Teachers who graduate from in K.S.A.'s universities are so weak in terms of grammar and language use. I believe that all the teachers need to study TOFEL and take some conversation training courses"

As it is mentioned later in the limitations of the study, the present study did not examine the language proficiency as a basic need since all teachers are graduates of English language departments from different faculties with varied specialties. Nevertheless, these two responses make it a need that deserves further investigation to stand on the level of language proficiency these teachers have and work out solutions. 


\section{The Discussion}

This research surveyed 114 elementary school EFL teachers to investigate the following questions:

1) How far Saudi EFL elementary school teachers are prepared for teaching in elementary schools?

2) What are present elementary school EFL teachers' attitudes towards EFL teaching at elementary levels in Saudi Arabia?

3) What are the suggested programs that fulfil the needs of present Elementary English language teachers in Saudi Arabia?

In this study, the main findings were as follows. First, there was no difference on the level of qualification between being a graduate of an educational faculty orart's one. Moreover, Al-Hazmi (2003) has indicated that both faculties' graduates take one course on EFL methodology, which he described as not enough, and both graduates spend the last semester of their programs at intermediate and secondary schools as novice teachers. However, the findings of the present study contradictedthat, as more than half graduates of both types did not receive pre-service training.Furthermore, $58.77 \%$ of the respondent teachers did not receive any training program concerning young learners teaching theory and pedagogy. Leading $83.34 \%$ of the targeted teachers to rely on their own previous experiences, which is in teaching teenagers in either intermediate, or secondary levels, or as $50.88 \%$ of them have experience in both levels. On the other hand, novice teacherswere left on their own in dealing with the challenges of thisage group and the entire teaching experience. In both cases, this affects the quality of learning. Cross (1995) indicated that putting untrained teachers into classrooms negatively affects the character of education. He stated, "It makes sense in both educational and economic terms to require all new teachers to be the products of a well-designed PRESET program."Further, he said"new entrants to schools should be familiar with routine school administration. They must know the objectives of EFL", but apparently $51.75 \%$ of the targeted teachers were unaware of the EFL young learners teaching policy in Saudi Arabia as clear intable 2. All the previous lead to the answer of the first question, to which the researcher has found that Saudi EFL elementary school teachers are not fully prepared for teaching in elementary school levels as more than half of them did not receive proper pre-service nor in-service training. Though according to Alshumaimeri (2011) teachers positively perceived their teaching skills and felt confident about their language competence, investigating their needs in the present study showed high demands on what are considered essential teaching aspects. Therefore, agreeing with Al-Hazmi (2003), the ministry of Education should encourage or require in-service teachers to continue their professional education through MA and certificate programs in TEFL/TESOL or other related areas that enable and facilitate the development of knowledge, skills and worthwhile habits in teachers.

As for the second question, teachers expressed a positive attitude towards teaching language to young learners. This comes with total agreement to the findings of Alshumaimeri (2011). He stated that the respondents to his study feel the elementary age is appropriate for English learning and English is better taught early so that learners have longer to study the language and that English is a necessity today. Teachers also expressed willingness to change ways and methods of teaching to fit the new context since that elementary level requires special qualifications as the majority of them are of previous experiences in teaching both intermediate and secondary levels. Cross (1995) indicated that attitudes that are the teachers' beliefs about education, their general motivation and willingness to be involved in extracurricular activities have such powerful effects on the classroom climate and learning.

For the third question, a list of the most needed programs managed based on the priorities of the targeted teachers was as follows.

1) Using technology in young learners' classrooms.

2) Methods and teaching strategies that suits young learners

3) Choosing and designing materials and activities that are suitable for the developmental stages of children

4) Young learners' language development evaluation and assessment

5) Young learners' classroom management

6) Young learners' Educational psychology

7) Lesson planning.

8) The English education teaching policy at elementary schools in KSA

9) Introduction to second language acquisition theory.

Two teachers' proposed programs through the second open question, are "Dealing with problems" and "Gifted 
students and special needs students programs" these can be added to the list above.

The First open question provided a good opportunity for teachers to express their views towards subjects they find sensitive since they reflect what really they experience in their working environments, in the same time it reflected their awareness and how far they are interested in making a change. These teachers' views, worries and concerns should be paid a lot of attention to work out problems that may stand as huge obstacles to many of them. It is necessary to prepare a comfortable motivating environment for the educational process to give its gains. Baleghiadeh and Gordani (2012) emphasized the influence of quality of work life factors on teacher motivation as their study indicated that the quality of work life accounts for $52 \%$ of English language teacher motivation in the Iranian secondary school context. They insisted on the fact that teachers should be involved and engaged in decision-making concerning their own growth as well.

The second open question raised a concern over EFL teachers' language proficiency, an issue that should be investigated urgently and dealt with. It is time that the Ministry of Education should apply language proficiency tests such as TOFEL or ELS to stand on their level of proficiency and to decide their linguistic needs to work on them. (Chaco'n, 2005; Eslami\&Fatahi, 2008; Akbari\&Allvar, 2010) have all agreed on relating teachers' sense of efficacy to language proficiency and thereby, relating it to students' achievement gains in an English-language teaching context.

\section{The Conclusion}

\subsection{Summary of the Findings}

This study aimed at investigating the readiness of EFL elementary school teachers to teach young learners and to inspect their attitudes and needs. The findings of the study showed that more than half of the targeted EFL elementary school teachers are not equipped with proper teaching knowledge concerning young learners. This urges for designing teacher-training programs based on their investigated needs and their suggestions of what they lack since their attitudes showed high enthusiasm towards teaching elementary students and regarded introducing English as a necessity at these levels.

AsElyas (2008) concluded, English is here to stay, but the people are reshaping, remolding, and adjusting it to suit them best. So teaching English to young learners at elementary schools has become an inevitability. In addition, it is expected for it to be introduced to younger levels soon. Consequently, teachers must be prepared and professionally supported pedagogically and on the language proficiency level as well. Teacher-training programs should be able to meet all EFL teachers' needs including elementary school teachers. It is time that well planned teacher training should be the Ministry of Education's No.1 priority since all the effort previously was centred on the textbooks and curriculum.

\subsection{The Recommendations}

Based on the survey, the teachers' views and responses, the searcher recommends the following:

- Designing the suggested programs urgently to level up the teachers' professional development.

- More needs analysis studies should be executed to investigate teachers' direct needs and satisfy them.

- Rising learning autonomy among teachers and encouraging them to be in charge of their own development.

- More attention to the issues rose by the teachers themselves concerning having to teach other subjects or in teaching in more than one school at the same time. This can be a distracting element of teachers' efforts.

- Teachers' views should be involved in designing their own training programs.

- Teachers should be part of developing curriculums for the young learners as they are the ones to execute them.

- More attention should be paid from the behalf of the ministry of education over schools' environments on both physical and administrative levels to offer some space for teachers to practice their creativity.

- More attention should be paid for enhancing language learning motivation among learners and parents.

\subsection{Suggestions for Future Studies}

- Future research should include teachers' language proficiency, which appeared to be an important aspect to be investigated as suggested by some of the teachers themselves.

- More needs analysis investigation should include certain targeted teachers on desired programs since they differ from teacher to teacher according to their personal lacks and needs. 


\section{Limitations}

The researcher on purpose overlooked investigating the teachers' language proficiency as a need since all English language teachers in Saudi Arabia at elementary schools are graduates of English departments and have at least the appropriate mastery of language to teach at this level. As most of the studies indicate that in some European and Asian countries elementary school teachers, who are not speakers of the English teach it as long as they have the minimum aspects of the language from their previous education. However, through the survey, the researcher found out that some teachers lack language proficiency. Some of them found difficulty in understanding some of the items that were present in the questionnaire which reflect their limited awareness in terms of English teaching methodology vocabulary. Moreover, there were demands from their behalf on training programs to improve their English language abilities.

\section{References}

Akbari, R., \& Allvar, N. (2010). L2 Teacher Characteristics as Predictors of Students Academic Achievement. TESL-EJ, the Electronic Journal for English as a Second Language, 13(4).

Al-Hazmi, S. (2003). EFL teacher preparation program in Saudi Arabia: Trends and challenges. TESOL Quarterly, 37(2), 341-344.

Al-Seghayer, K. (2011). English Teaching in Saudi Arabia: Status, Issues, and Challenges. Riyadh, Saudi Arabia: Hala Print Co.

Alexander, C., \& Fuller, E. (2005). Effects of Teacher Qualifications on Student Achievement in Middle School Mathematics in Texas. Paper presented at the American Educational Research Association Annual Meeting.

Alshumaimeri, Y. A. (2011). Saudi EFL Teachers? Perceptions of Teaching English in Public Elementary Schools. College of Education Journal, Kafr Al Skaikh University, 5.

Alwan, F. (2000). Towards Effective In-service Teacher Development in The United Arab Emirates: Getting Teachers to be in Charge of their own Professional Growth. University of Bath, Department of Education. Retrieved from http://files.eric.ed.gov/fulltext/ED503768.pdf

Aydin, S. (2012). Factors Causing Demotivation in EFL Teaching Process: A Case Study. The Qualitative Report, 17, 1-13.

Baleghiadeh, S., \& Gordani, Y. (2012). Motivation and Quality of Work Life among Secondary School EFL Teachers. Australian Journal of Teacher Education, 37(7), 30-42.

Brown, J. D. (1995). The elements of language curriculum: A systematic approach to program development. Boston, Massachusetts: Heinle \& Heinle Publishers.

Cameron, L. (2001). Teaching languages to young learners. Cambridge: Cambridge University Press.

Chaco' n, C. T. (2005). Teachers? Perceived efficacy among English as a foreign language teachers in middle schools in Venezuela. Teaching and Teacher Education, 21, 257-272.

Chou, C. (2008). Exploring elementary English teachers? Practical knowledge: A case study of EFL teachers in Taiwan. Asia Pacific Education Review, 9(4), 529-541.

Cross, D. (1995). Language teacher preparation in developing countries: Structuring pre-service teacher training programs. Forum, 33(4), 34. Retrieved from http://dosfan.lib.uic.edu/usia/E-USIA/forum/vols/vol33/no4/ p34.htm

Donaldson, M. C. (1987). Children's minds. London: Routledge.

Elyas, T., \& Picard, M. (2010). Saudi Arabian educational history: Impacts on English language teaching. Education, Business and Society: Contemporary Middle Eastern Issues, 3(2), 136-145.

Elyas, T. (2008). The Attitude and the Impact of the American English as a Global Language within the Saudi Education System. Novitas-ROYAL, 2(1), 28-48.

Eslami, Z. R., \& Fatahi, A. (2008). Teachers' Sense of Self-Efficacy, English Proficiency, and Instructional Strategies: A Study of Nonnative EFL Teachers in Iran. TESL-EJ, 11(4).

Gonzalez, A., Montoya, C., \& Sierra, N. (2002). What do EFL Teachers Seek in Professional Development Programs? Voice from Teachers. Ikala, revista de lenguaje y cultura, 7(13). 
Igawa, K. (2008). Professional Development Needs of EFL Teachers Practicing in Japan and Korea. Shiten'no International Buddhism's University, 4. Retrieved from http://www.shitennoji.ac.jp/ibu/images/toshokan/ kiyo45-21.pdf

Javid, C., Farooq, M., \& Gulzar, M. (2012). Saudi English-Major Undergraduates and English Teachers' Perceptions Regarding Effective ELT in the KSA: A Comparative Study. European Journal of Scientific Research, 85(1), 55-70.

Kusumoto, Y. (2008). Needs Analysis: Developing a Teacher Training Program for Elementary School Homeroom Teachers in Japan. Second Language Studies, 26(2), 1-44.

Montessori, M. (1983). The Secret of Childhood. London: Sangam Books.

Rice, J. K. (2003). Teacher quality: Understanding the effectiveness of teacher attributes. Washington, DC: Economic Policy Institute.

Richards, J. (2011). Competences and Performance in Language Teaching. Cambridge: University press.

Sanders, W. L., Wright, S. P., \& Horn, S. P. (1997). Teacher and Classroom Context Effects on Student Achievement: Implications for Teacher Evaluation. Journal of Personnel Evaluation in Education, 11, 57-67.

Sanders, W. L. (1998). Value added assessment. School Administrator, 11(55), 24-27.

Stronge, J. H. (2000). Teacher evaluation and student achievement. Washington, DC: National Education Association.

Tizard, B., \& Hughes, M. (1984). Young children learning. London: Fontana.

Wati, H. (2011). The Effectiveness of Indonesian English Teachers Training Programs in Improving Confidence and Motivation. International Journal of Instruction, 4(1).

Wells, G. (1999). Dialogic enquiry: Towards a sociocultural practice and theory of education. Cambridge: Cambridge University Press.

Zaid, M. (1993). Comprehensive analysis of the cultural system of teaching English as a foreign language in Saudi Arabian intermediate schools (Unpublished doctoral dissertation). The University of Colorado, Boulder.

Zuheer, K. (2013). Developing EFL Teachers' Performance at Sana'a Secondary Schools in the Light of their Professional and Specialist Needs. Submitted for the Ph.D. Degree, Cairo University, Institute of Educational Studies, Curriculum \& Instruction Department. Retrieved from http://files.eric.ed.gov/fulltext/ED541645.pdf

\section{Copyrights}

Copyright for this article is retained by the author(s), with first publication rights granted to the journal.

This is an open-access article distributed under the terms and conditions of the Creative Commons Attribution license (http://creativecommons.org/licenses/by/3.0/). 